\title{
'A Continuous Process of Becoming': The Relevance of Qualitative Research into the Storylines of Law
}

\author{
Danielle Antoinette Marguerite Chevalier*
}

\begin{abstract}
The maxim 'law in books and law in action' relays an implicit dichotomy, and though the constitutive nature of law is nowadays commonly professed, the reflex remains to use law in books as an autonomous starting point. Law however, it is argued in this article, has a storyline that commences before its institutional formalisation. Law as 'a continuous process of becoming' encompasses both law in books and law in action, and law in action encompasses timelines both before and after the formal coming about of law. To fully understand law, it is necessary to understand the entire storyline of law. Qualitative studies in law and society are well equipped to offer valuable insights on the facets of law outside the books. The insights are not additional to doctrinal understanding, but part and parcel of it. To illustrate this, an ethnographic case study of local bylaws regulating an ethnically diverse public space of everyday life is expanded upon. The case study is used to demonstrate the insights qualitative data yields with regard to the dynamics in which law comes about, and how these dynamics continue for law in action after law has made the books. This particular case study moreover exemplifies how law is one of many truths in the context in which it operates, and how formalised law is reflective of the power constellations that have brought it forth.
\end{abstract}

\section{Introduction}

What worries me are the arguments that people articulate with less and less hesitation. The economic arguments people first used are more and more traded in for straightforward statements about 'blacks' that should be moved out. I ask for awareness and extra attention for arguments offered to adjust the legal regulations. It cannot be that on the basis of the perception of a limited group another group is driven from the public space. I ask myself on what grounds this should be.

These words come from a chief of police, written in a letter to his mayor to express his deep concern regarding proposed legislation and implementation of certain reg- ulations in his district. The year is 2003, the district is part of a mid-sized provincial city in the south of the Netherlands. The public space referred to is a small neighbourhood shopping square, a vibrant shared space of everyday life that is intensively used by a highly diverse, multi-ethnic community. The legal regulations referred to are measures restricting the use of the square and include a ban on gathering with three or more persons, closed circuit television surveillance (CCTV) and a ban on use of psychoactive substances.

The quote and the particular case are contextualised further on in this article. Here the citation is offered to present the point that legal regulations do not appear out of the blue; regulations have a story that commences prior to their legislative emergence. To truly understand law is to understand its story, and this article propounds that qualitative case studies offer valuable insights into the full story of law. They can offer light on not only how formal law works in a context, but also - and even more importantly - how that context influences the coming about of formal law.

The formula 'law in books and law in action' has ingrained itself in sociolegal scholarship to denominate formal law and the context in which it operates. Roscoe Pound first advanced the phrase as title to an article, published in the American Lam Reviem. ${ }^{1}$ The distinction between law in books and law in action is, in the words of Pound, that the former are rules that 'purport to govern the relations of man and man' and the latter are the rules 'that in fact govern them'. Pound argued that the two diverge and stated, the time frame being 1910, that 'Today we are manifestly in a period of stability.' Pound found this state worrisome. Contrary to periods of growth, in which law is developed, periods of stability are marked by the summing up of 'the juristic activity of the past' and of working out details and applying minor corrections. In periods of stability, jurists focus on perfecting existing law, instead of addressing 'new problems or of meeting new situations of vital importance to present-day life'. ${ }^{2}$ The adherence of legal thought to an idealistic interpretation of legal science induces that 'justice in concrete causes ceases to be (the) aim' of jurists and this in turn leads to, Pound warned, a gulf 
between legal justice and social justice. ${ }^{3}$ In the face of this hazard, Pound argued, 'it is the work of lawyers to make the law in action conform to the law in the books, (...) by making the law in the books such that the law in action can conform to it.' 4

The dichotomy inherent in Pound's positioning of law in action versus law in books echoes through in many of the studies of law and society that have since built on Pound's 'law in action' adage. These studies first continued with the instrumentalist understanding of law propounded by Pound; later on research in law and society shifted towards a constitutive approach. ${ }^{5}$ Rather than considering law autonomous from social life, law became understood to be 'neither distinct from society' nor to 'act on society from without'. ${ }^{6}$ This constitutive turn brought forth rich research focusing on the presence of law in society, investigating how people experienced law in their everyday life. ${ }^{7}$ Alternatively, attention is also drawn to what people themselves experience as law, the 'social norms and values that dominate life itself, even though they have not been posited in "official" law'. ${ }^{8}$

Both approaches though keep this implicit notion of 'official' law, of law in books, as the baseline; formalised law forms the starting point of the investigations. However, law in books has a storyline that commences before its formal coming about. As Pound asserts in his 1910 essay: 'law has always been and no doubt will always continue to be in a process of becoming'. 9 Pound's worry was that in the period of stability he detected in his time, the juristic activity was limited to refining established principles instead of developing new '(emphasis added)' law better suited to respond to the 'new situations of (...) present-day life'. ${ }^{10}$ Law is a dynamic process, and Pound argued, the development of law should

3. Ibid., at 30

4. Ibid., at 36

5. L.B. Nielsen, 'Situating Legal Consciousness: Experiences and Attitudes of Ordinary Citizens about Law and Street Harassment', 34(4) Law \& Society Review 1055, at 1058 (2000).

6. C. Geertz, Local Knowledge. Further Essays in Interpretative Anthropology (1983), at 232.

7. See, e.g.: S.E. Merry, Getting Justice and Getting Even. Legal Consciousness among Working-Class Americans (1990) and P. Ewick and S. Silbey, The Common Place of Law: Stories from the Everyday (1998).

8. Cfm M. Hertogh, 'A 'European' Conception of Legal Consciousness: Rediscovering Eugen Ehrlich', 31(4) Journal of Law and Society (2004). Hertogh offers a comprehensive overview of the field of legal consciousness studies and distinguishes between an American and a European conception of legal consciousness: the first focusing on perceptions of official law, the second investigating what people perceive as law. One objection Hertogh raises with the American conception, and in affiliation in Pound's work, is the fixed definition of law, with exclusive focus on law as 'rules laid down in a politically constituted society.' (Ibid., at 466) Expanding on the more inductive European conception, Hertogh argues to not only look at how people experience official law, but to also investigate what people experience as 'law', because 'both views are sides of the same coin'. (Ibid., at 480) Again, parallel to the division between law in books and law in action, a dichotomy is imbued. The division alters from books versus action, to the law in books versus the law in action. In other words, it is not just the setting of books and action that is juxtaposed, the content of the entity law in these two settings is also differentiated.

9. Pound, above n. 1, at 22.

10. Ibid. encompass new law addressing the external challenges raised by present-day life. In other words, present-day life should be conducive to the development of law. It is not only law impacting present-day life; it is also present-day life impacting law. The dynamic is not onedirectional, but rather circular: the continuous outcome of the interplay between juristic activity and present-day life.

These dimensions can be denominated law in books and law in action, as the phrase has proven its fetching resonance. A caveat must be noted though with regard to the innate connotation of a dichotomy between books and action. As fetching as the phrase is, as ingrained is the instinctive division between the two. This can distract from the possibility of the difference between law in action and law in books to be merely a point in time. The dimension of law in action, as the context in which law in the books comes about and subsequently operates, should be further differentiated into dimensions of past and present. The prelude to the emergence of a regulation is an important storyline in the narrative of law: regulations and rules originate from somewhere. 'Rules', in the words of Howard Becker, 'are the products of someone's initiative'; they are the products of 'moral entrepreneurs'. ${ }^{11}$ Understanding law as a process entails understanding its different dimensions, books and action, past and present, as well as the interplay between these dimensions.

In the following a singular case study is discussed to illustrate how the different dimensions and their interplay can be researched, and what such an investigation yields in insights. Taking the 'process of becoming' of law to the concrete level of a regulation, one can discern the prelude to a regulation, the coming about of the regulation, and the regulation subsequently 'in action'. At the centre of the case study presented here are specific bylaws regulating public space. The regulations are of a restrictive nature and are meant to regulate the social life of a public space. The public space is a shared space of everyday life, with a varied spectrum of users who diverge in their ethnic composition, cultural frames of reference and socio-economic standing. In such a context, developing law in the books 'such that law in action can conform to it', means a differentiation in phose law makes it to the books. At the micro-level of a local bylaw, the social power dynamics surrounding the coming about of law can be clearly distinguished and explored.

In the following, first the methods that were used to research this case are put forward, second the case study is introduced, and third the analysis of the data retrieved through the qualitative research is expanded upon. In the conclusion, the contribution of the qualitative section of the investigation of this particular case study is reviewed and discussed.

11. H.S. Becker, Outsiders: Studies in the Sociology of Deviance (1991[1963]), at 147. 


\section{Methodology}

The lion's share of the data presented in this article was acquired through qualitative research using ethnographic methods. The overall argument put forward is that ethnographic methods offer essential insights that do not materialise by confining the investigation to 'the books', and, moreover, inductive qualitative research offers possibilities of theory formation. In this section I expand rather elaborately on the methods I used to investigate the case presented above. I explain the choices I made with regard to methodology, and how I executed the actual research. It is common practice in qualitative research to offer such an overview, and it offers a base to discuss the analysis made with regard to the case study in the next section.

\subsection{The Larger Research Frame}

The case study presented in this article is one of three cases researched as part of a larger project investigating the juridification of social norms in public spaces. ${ }^{12}$ The research was carried out by one single researcher, ${ }^{13}$ using different methods of investigation, different sources of data and different theoretical perspectives. At the basis of the investigation was a quantitative nationwide survey inquiring after the numbers and characteristics of local bylaws on substance use. From this quantitative inventory three case studies were selected, to investigate how and why these regulations came about in a given context, and what the subsequent effects were. The ethnographic methods employed are expanded upon below. Additionally, written sources of data were researched through document analysis and legal research methods, including the analysis of policy papers, minutes of local and national political debates, municipal statutes plus their explanatory memoranda, the tracing of legal procedures of court cases, and anything else that turned up in the course of the research. One example of the latter is the letter from the head of police quoted in this article; this letter was part of a police archive on issues regarding the square. Another strand of document analysis consisted of reviewing news coverage in local and national media. Furthermore, semi-structured interviews were arranged with professionals and stakeholders linked to the research sites. Professionals are persons with a professional relationship with the space, and who talked to me in their professional capacity. With regard to the case presented here, the interviewed professionals included the municipal safety coordinator of the district, the legal counsellor for the municipality, policy officers assigned to the area and a representative of the dominant housing corporation. Stakeholders included mem-

12. Culminating in the PhD thesis Playing It by the Rules. Local Bans on the Public Use of Soft Drugs and the Production of Shared Spaces of Everyday Life. Defended June 2015, University of Amsterdam.

13. The disciplinary background of the researcher is a combination of law and cultural anthropology. bers of the Association of Entrepreneurs, the chairman of a neighbourhood council and a journalist. ${ }^{14}$

\subsection{The Choice for Qualitative Research}

The overall research was jumpstarted out of curiosity for the seemingly sudden appearance and proliferation of local bans on the public use of soft drugs, ${ }^{15}$ which occurred in the Netherlands in the 2000s. A quantitative survey was set up to inventory the number and kinds of bans, and the juridical dimension of the regulation was investigated. Both the quantitative survey and the legal exploration threw up more questions than they answered, ${ }^{16}$ and the biggest question remained what these bans were about: why had they come about, in the manner that they did, at the moment when they did and in the location where they did? A starting point to answering this query is to decipher how they came about. At this point the strategic choice was made to continue with an in-depth qualitative exploration of three case studies. The term 'exploration' used here refers to the inductive nature of the investigation: there was no pre-set hypothesis to be tested. Rather, the research evolved as an iterative process between data and theory, while searching for an explanation of the issue under investigation. ${ }^{17}$ Additional to the questions above, I was interested in the effect of the bans 'on the ground'. Subsequently I also set on researching the locations in which the bans figured, among which the shopping square discussed in this article. As I will exemplify in the next section, the ethnographic fieldwork on site also contributed substantially to understanding why the ban materialised as it did in the first place.

14. During my fieldwork a journalist from the regional newspaper Brabants Dagblad had taken up residence on the shopping square for a period of three months. Twice a week he wrote an article on 'the blackest neighbourhood of Brabant'. Brabant is the province in which the city of the shopping square is located.

15. Soft drugs and its counterpart hard drugs are popular terms used in reference to the formal categories of, respectively, List II and list I of the Opium Act. Whereas hard drugs are deemed to hold unacceptable risks for public health, soft drugs are generally deemed less addictive and less harmful. The legal regimes of the two categories differ accordingly. Though qat was not on either list of the Opium Act at the time of the research, local bans on qat did turn up in the national survey and were subsequently factored into the overall research design.

16. To start with, there turned out to be many more of such bans than media reports had estimated: the inventory disclosed 81 bans versus 25 the media had counted. Moreover, many of the bans demonstrated formal deficiencies. One example being that of the 81 municipalities which had adopted a said ban, 48 had formulated it to apply for the entire municipal territory. A similar formula on the use of alcohol had however been repeatedly negated by government and the same reasoning can be expected to hold for the case of soft drugs: There needs to be a direct cause for implementing the regulation, founded in the maintaining of public order. If the public order of the entire territory of a municipality is under threat of being subverted, a ban on the public use of alcohol is considered inadequate. If such a threat is not in place, a total ban is considered disproportionate, in accordance with Art. 3:4 of the Algemene Wet Bestuursrecht, the General Administrative Law Act. Consult also: Response by the Minister of Justice to Parliamentary Questions (Tweede Kamer, Vergaderjaar 2010-2011, Aanhangsel 1885) and Letter to Parliament by the ministers of Health, Justice, and Home Affairs (Tweede Kamer, Vergaderjaar 2008-2009, 27565, nr. 75).

17. A. Bryman, Social Research Methods (2004). 


\subsubsection{Ethnographic Fieldwork}

The ethnographic fieldwork consisted of observations, participant observations and street interviews. The timeline of the fieldwork ran from spring 2010 to autumn 2011. Approximately forty visits were carried out to the shopping square, in time slots varying from one to five hours at a stretch.

My observations concerned the social dynamics of the square: when was it used, by whom and in what manner. I focused on the people in the space, how they behaved and with whom they interacted (or not), but also included observations on physical layout of space such as formal and informal signs and notices put up. I did my observations from the space itself, sharing the cold, the heat, the rain, the noise, and the smell with those I observed. At times, I would position myself in the middle of the setting and for example sit on the much used - and much vied-over - public bench on the square. In other instances, I would take a second-row position, by settling down as a customer of one of the enterprises or by locating myself at the edge of the site, out of direct sightlines. In all instances, I could easily accost others and try to strike up a conversation. Moreover, and more importantly, people could accost me and question me. In many cases, they did. I took notes overtly, and in more than one instance my collocutor would take my notepad away from me, check what I had written, comment on my terrible handwriting, and correct and add to my written notes.

During my hours of observation, I conducted numerous street interviews; informal conversations held with whomever was willing to engage themselves with me. The overall intent of these interviews was to discover existing knowledge of and perceptions on the bans in place on the shopping square. Sometimes these conversations were initiated by me, sometimes by my collocutor. Some people I spoke with on multiple occasions, and some of them I came to consider key informants. The majority of these conversations were one-on-one, though at times I would find myself to be conversing with a group.

To structure the informal exchanges I asked everyone the following same three questions: (1) Which three words would you use to describe this space? (2) How often do you come here and why? (3) Is anything forbidden here that is not forbidden elsewhere? The first question allowed to gauge how people perceive a space, and eased a further exchange. Sometimes, but certainly not predominantly, reference would be made to the restrictive measures in place on the square. The second question functioned to get an idea of the importance of the shopping square to a person in the daily flow of life. The third question zoomed in on the reason I was actually there. The question was meant to make clear how many of the people using the square were actually aware of the issue that had drawn me and my research to this particular place: the municipal ban on the public use of psychoactive substances implemented on the square. ${ }^{18}$ In combination, the three questions offered a tangible grasp of how the regulations were perceived by my collocutor, and in which context that perception had been formed.

\subsection{Theoretical Orientations}

The qualitative research conducted did not aim to be merely descriptive in investigating the ban, and tracing how it came about and how people experienced and perceived it. The comprehensive endeavour was to develop a 'grounded theory' ${ }^{19}$ on why local bans that restrict specific usage of shared public spaces come about. Accordingly, the research tactic was inductive: the case was explored in constant interplay with theory. Data was analysed as it came in, and the ongoing analysis informed the next steps in data collection. Concretely, the iterative process took form through 'memoing': recording the products of analysis while processing incoming data, and refining memo's in multiple rounds of analysis into more abstract ideas and conclusions. ${ }^{20}$

Additionally, the focus on the specific context in which the legal issue under scrutiny functioned, gave influx to a whole body of theory connected to that context of public space. By moving beyond the direct legal body of thought, opportunity arose for interdisciplinary inspiration. One example of such interdisciplinary inspiration revolves on the work of Henri Lefebvre. In the course of the research it became clear that space and law hold many similarities in their coming about. For the spatial realm, Lefebvre has refined the traditional dichotomy between planned and lived into a conceptual triad, arguing that that space comes about, in his words 'is produced', through the interplay of three linked dimensions: planned, perceived and lived. ${ }^{21}$ Tilting the analytical lens from a dichotomy to a three-dimensional interplay likewise with regard to law, offered new insights and understanding on how law comes about. Building on the work of Lefebvre, I commenced to investigate the bans as they were 'in the books', and as they were perceived by the people under the regime of these bans, and as the bans actually figured in the daily life of the shopping square. In combination, these dynamics explained why the restrictive regulations had first come about on the shopping square, and why their actuality continued to be reiterated.
18. The ordering of the interview questions from general context to specifically the bans is taken from the work of P. Ewick and S. Silbey, above n. 7

19. This term was first introduced by: B.G. Glaser and A.L. Strauss, The dis covery of grounded theory: Strategies for qualitative research (1967). My application of the concept however is inspired by the outlines of Corbin, cfm J. Corbin and A. Strauss, Basics of Qualitative Research: Techniques and Procedures for Developing Grounded Theory (2008).

20. Corbin and Strauss, above n. 19, at 117

21. H. Lefebvre, The Production of Space (1991 [1974], at 38-39. 


\section{The Case Study}

The case under scrutiny here concerns municipal bans on a small neighbourhood shopping square in a provincial town in the Netherlands. In the following I first describe the setting and the people, that is to say the shopping square and the people on it, and then continue with describing the regulations set to regulate this space and the people using it.

\subsection{The Square}

The square in question is a small low-end shopping square on the outskirts of a provincial city situated in the south of the Netherlands. The shopping square is laid out in a $\mathrm{U}$ shape, with three sides containing retail space and the opening to the south side. The three sides with shop space all have a covered archway, shielding pedestrians from the rain and sun. The east arch is twostoried, and on the top level four privately owned apartments are situated. Along the open south end runs the main access road into the neighbourhood, which in turn connects to the main thoroughfare to the freeway circumventing the city.

The square supports mainly shops and restaurants. The main attraction is the Aldi, a discount supermarket chain store. In addition, there is an Islamic butcher shop, an Islamic grocery shop, an Islamic bakery, a Dutch bakery, a Pakistani phone house, a Chinese restaurant, an Egyptian-Italian-Greek restaurant, a snack bar, and a lawyer's office. The majority of the shops are not owner-occupied and most of the retail property is owned by a distant real-estate investment company. The range of shops on offer is volatile, and from the early 2000s municipal reports invariably state that 'There are habitually a few shops empty on the square.' In the direct vicinity, the square is surrounded by residential flats that predominantly house ethnic Dutch senior citizens.

The small shopping square is situated in a post-war neighbourhood built in the 1960s and 1970s, according to the dominant urban planning ideas of that era: it is a car-friendly area, with a lot of communal green and high-rise flats. The area was developed for and originally dominated by lower middle-class and middle middleclass ethnic Dutch residents. Approximately $30 \%$ of the residences in the neighbourhood are owner-occupied. The remaining $70 \%$ consists predominantly of lowincome social housing and is almost exclusively owned by a single housing corporation. In the 1990s the composition of the population started to shift. At the time of fieldwork the moving index hovered around 20\%, meaning that one in five residents leave the neighbourhood every year. The neighbourhood officially houses a little under 7,000 inhabitants, though the unofficial count is possibly much higher. In the district an estimated $12 \%$ of the inhabitants are older than 65 , almost $30 \%$ are eighteen years old or younger, circa $40 \%$ are native Dutch, and around $50 \%$ are of non-Western descent. No official figures are available on the back- ground of the population of non-Western descent; a community worker estimated that a quarter has a Moroccan background, a quarter has a Turkish background, $15 \%$ is of Antillean descent, and $15 \%$ is of Somali descent. One known fact is that the city has one of the largest Somali communities of the Netherlands, and the area surrounding the shopping square houses a high concentration of Somali residents.

\subsection{The People on the Square}

The shopping square is the central social locus to the neighbourhood, a shared space of everyday life. Its daily users can be categorised into immediate residents of and right next to the square, the shopkeepers, and the visitors. The visitors can furthermore be categorised into 'shoppers' and 'socialites'. This classification is not exhaustive, and the denominated categories are not exclusive, but the proposed ordering facilitates in getting a grasp of the dynamics on the square.

\subsubsection{The Residents}

The residents on and directly adjacent to the shopping square are predominantly native Dutch senior citizens. One of the owner-occupied apartments on the square itself houses a couple that has lived there since the structure was built in the late 1960s. They reminisce about how it used to be:

The square was much prettier. There were trees in the middle of the square and there was a sandwich restaurant. The entire neighbourhood came there on Sundays to get an ice-cream. The first fifteen years everything was good.

From their perspective, however, things have changed, and for the worse:

those who could leave have left [...], all the nice people have left.

Not all the immediate residents are as negative; others decipher the life of the shopping square in a different manner:

I like it here. I moved here from a neighbouring village and you have your youth there, mind you. I've been living here since December and there is youth here. Sometimes they bother me, like the other day they were lighting fireworks and I thought the windows would crack [she laughs], but no they don't really bother me. I had heard the stories, about this square, that it was very criminal, with drugs and everything, but well, there are criminals everywhere and I experience no nuisance at all. I live here on the square, in that flat over there. I walk my dogs in the evening and I don't feel unsafe. I have contact with the other people in my flat and on the street, those are people from another culture. They say hi and I say hi. I like people and I don't care whether they are white, black or yellow. 
The residents of the flats bordering the square have a prime view over what goes on there, and the atmosphere on the square permeates through their living room windows. Noise nuisance is a much-expressed complaint and is registered often with the police. Especially for those who are not mobile and whose lives play out in the close vicinity of their home, the situation on the square has an important impact on their daily routines.

\subsubsection{The Shopkeepers}

The shopkeepers are a heterogeneous and split group. For most of the smaller entrepreneurs their enterprise is, in the words of the local policeman, 'not making them a fortune'. An Association of Entrepreneurs exists, but mostly in a dormant state. For the shopkeepers, the atmosphere on the square impacts on its attractiveness for potential clientele and thus their revenues. Their ideas on what constitutes an attractive square, however, do not necessarily line up. Some of the shopkeepers experience nuisance and feel that those 'hanging out' on the square give a negative impression. The Islamic butcher shop and the Dutch bakery put up similar notices in their shop windows, requesting people not to loiter in front of their shops. The proprietor of the Dutch bakery owns both the business and its premises, and is an active spokesperson. He regularly speaks out in the media and actively lobbies the municipal authorities for more intervention. For other shopkeepers, the people who are viewed by some to cause nuisance are their clientele:

Those guys are my customers. The more of them the better for me. They don't cause me any nuisance. They come to the square for something and then they hang about a while. I never called in nuisance to the police. [...] Sure, they come into my place as well and try to pay with a five-hundred-euro note. Of course they are dealing, but what can you do? If I ask them where they got the money they tell me to mind my own business. For me it's a good square, I've never had any trouble, never had any violence in my shop. In the beginning, I was worried about the Antilleans, but they are very nice people.

\subsubsection{The Visitors}

The visitors to the square can be categorised into two groups: the shoppers and the socialites. Of course, the activities of shopping and socialising often overlap. The shoppers, however, come to the square with the main purpose of doing their shopping. The socialites come to the square with the main purpose of socialising.

The shoppers can in turn be subcategorised by their mode of transportation. Some of the shoppers choose the shopping square because it is compact, convenient and car-friendly. The square is an easy turn off from the main thoroughfare north out of town and more often than not it is possible to park the car right in front of the shop. In the early mornings, heavy articulated trucks easily find room to park and get some sandwiches or some cans of energy drink from the Aldi supermarket. They use the square out of convenience.

For the second category of shoppers, the square plays a much more crucial role in their daily lives. The square is their nearest shopping point and they lack the mobility to opt for other shopping venues. These shoppers come on foot: young mothers accompanied by three small children, and elderly people wheeling a pushcart. They depend on the square for their daily groceries and the square is important in their perception of their residential environment. It is also important in their daily social interactions. The Dutch baker for example knows many of his older clientele by name, and often also their health status and the recent achievements of their grandchildren. In the other shops as well many customers are recognised and greeted with personal inquiries. Shoppers meet familiar faces on the square and use the opportunity to exchange pleasantries and gossip.

The socialites are also subcategorised here into two groups. One the one hand are the Somalis, congregating on the west side of the square around 'their' metal green bench and in and around cars parked on the parallel road to the south side of the square. They come to the square to meet others, to socialise, and to discuss the state of the world. Many of them do not frequent the shops at all. Their voices are loud and their gestures are embodied. They do not speak Dutch - sometimes not at all and certainly not amongst themselves. The age range of the group is from early twenties to quite elderly and the group consists almost solely of men. They show little interest in persons on the square not belonging to their group. Most notably, while socialising on the square they conspicuously and extensively consume and trade in the psychoactive substance qat. ${ }^{22}$

The other category of socialites consists of adolescents, from mid-teens to late twenties. Again, the members are predominantly male. According to the police the youngsters are divided into subgroups, loosely along lines of ethnicity, with Antilleans on the one hand and a predominantly Moroccan group on the other. During my fieldwork I did not discern this division; all the youths frequenting the square knew each other and intermingled. The lingua franca is Dutch. Disruptions between group members occur intermittently and are at times clearly noticeable from outside the group, influencing the general atmosphere on the square. The youths frequent the phone shop and the grill room and their usual position is in front of these two establishments. Their substance use revolves around alcohol and cannabis, next to large quantities of energy drinks. They come to make an appearance and the square is their stage. As the local policeman narrates: 'These boys have no interest in the hangouts created for them near outlying sports fields. They come to the square to see and be seen.' For

22. Qat refers to the leaves and twigs of the plant Catha edulis. Chewing on the fresh leaves and twigs of this plant produces a mild euphoric effect. The use of qat is connected to deep socio-cultural traditions, often equalled to drinking coffee. Up till January 2013, qat was not an illegal substance in the Netherlands. See also: D.J. Korf, T. Nabben and M. Wouters, Evaluatie Qatverbod (2015). 
this group in particular the shopping square is a stage, as much as it is a site of leisure and a space for socialising.

For those whose reference is the rhythm of white-collar work, the lolling about of youths during daytime hours equates to unemployment and idleness. In part, this is undoubtedly correct. However, a fair share of those using the space of the shopping square as their living room come there to relax before or after their work; being employed in blue-collar jobs, their work is often cast in shifts, not bound to a nine-to-five regime.

\subsubsection{Competing Claims to the Shared Space}

In the shared everyday space of the shopping square different groups stake a claim on the space, most notably the elderly residents who are predominantly native Dutch, young adolescent males of mostly Antillean and Moroccan background, and Somali men of all ages. Each of these groups has their own mode of using the space they share with others, moulding the space to comply with their view and use of it. At some points these modes converge, at other points the modes diverge, and at times the modes are in practice irreconcilable.

The Somali men perceive the public space of the shopping square well suited to congregate and socialise. The accompanying ritual of qat links them to their roots and each other. The bans on congregating and substance use are in contrast with how they perceive and use the square. Though they are only intermittently enforced, the possibility of this happening always hovers in the background. The young adolescents, growing up in the neighbourhood, consider the square as their turf. Often coming from large families housed in small units, the square is like their living room. Likewise, the bans and their possible enforcement hover in the background of their perceptions. To many of the elderly residents the appreciation of the shopping square is tied in with how it used to be, when there was still a large enough clientele to support a hairdresser, a Dutch butcher where one could get a good piece of pork, a florist, an ice-cream parlour. It was a place to stroll and meet neighbours, decent white-collar workers like themselves. The place as they encounter it now is one of empty shop-fronts, a low-end supermarket, a phone shop, two Islamic butchers, and congregations of dark-skinned men they find intimidating. The regulations echo their views on how it should be.

The space of the shopping square is a physical locality, but it is more than a mere physical phenomenon, more than an 'empty medium'23 'in which life transpires'. ${ }^{24}$ In the same way that societies produce space, space in its turn produces societies. The shopping square is used by people to live their daily lives, and they attempt to manipulate the space into accommodating their use of it and their views on the appropriate use of it. As such, the square is the physical expression of the power dynamics

23. Lefebvre, above n. 21, at 87

24. H. Molotch, 'The Space of Lefebvre', 22(6) Theory and Society 887, at 888 (1993). convening in that space. The case study under scrutiny here demonstrates how such power dynamics can culminate into the coming about of legal interventions.

\subsection{The Lam}

On the shopping square, closed circuit television surveillance (CCTV) was installed in April 2004. At the same time a ban on gathering was enacted, with gathering being defined as a congregation of more than three people, of whom it can be assumed that their gathering is linked to repeated nuisance. A ban on the public consumption of alcohol had already been in effect on the square from 2002 onwards. The local bylaws were amended in 2005 to offer the possibility of banning psychoactive substances in designated public spaces, and eventually in December 2007 a ban specifically on the use of and trade in qat was put into effect on the shopping square.

The restrictive regulations did not appear out of the blue, but were the result of a very strong bottom-up push. The municipal bans were not a top-down initiative, but closely connected to a series of events that give leeway to a certain faction of the users of the shared space of the square to initiate legal back-up to their perceptions and views. This becomes clear when looking at the historical context.

\subsubsection{Backdrop to the Regulations}

In the summer of 2003 the shopping square made the national news. On a Monday afternoon in late July a fight broke out on the square. Initial police reports stated that over eighty people were involved in a street fight, using sticks and clubs. The image conjured up through the newspaper articles is one of a large rumble in clear daylight between two opposing gangs of Somalis versus Antilleans, bashing each other in the central public space of the neighbourhood. A collocutor in a street interview, however, downplays the intensity of the event: 'In the newspaper it said we were fighting with steel bars, but that's rubbish. There was this one guy with the rod of a vacuum cleaner he had just bought.' The police as well report that the incident was less serious than initially broadcasted, but this mitigation received little media attention.

The news of the clash caught the national attention and imagination in the backwash of an incident two weeks previously in the same city, when an eighteen-year-old male had been beaten to death in front of his twin brother and a friend, in a street robbery gone awry. The four perpetrators were strangers to the victims, under the influence of alcohol and cannabis at the time of the failed robbery and violent murder. They declared they had been bored and had wanted to acquire some cash to go out that night. In the press coverage of the incident, two of the four perpetrators are specifically identified as Antilleans. Though the two incidents were unconnected, in combination they triggered the public sentiment on ethnic youths in the city. There had already been other incidents relating to public safety in the region, but this episode firmly consolidated the image in the 
collective consciousness that the shopping square was a troubled area. A public outcry for strong action ensued. As a municipal officer reminisces, the societal pressure on the mayor to do something became enormous.

The comprehensive augmentation of regulations to control public order seems a logical, sequential response to the general sentiment on the status of public order and safety. However, within the municipal organisation not everyone applauds the chosen track. As a municipal legal counsellor recalls, in his perception the petitioned regulations were an ill-considered political response cast in a legal mould:

We - the legal staff I mean - were raised with the idea of minimizing the amount of regulations. The way it went was that we got a whole package of regulations. We managed to ditch a few of them. In general, and certainly with regard to the local bylaws, but also in general it is my view that you can make as many rules as you want, but you always have to test them on their concrete applicability: can you use it? Can you enforce it? It is not enough to say look I found this wonderful regulation in the local bylaws of Rotterdam - really, one can find anything in there we should get it too. I mean, does it gain us anything? Or is it just playing to the gallery, because it's in fashion?

Likewise, the police head of the district voiced strong objections to the series of restrictive regulations that were being proposed. The events in the summer of 2003 led him to write a pressing letter to the mayor, a short section of this letter was reproduced at the start of this article. The head of police expresses his concerns about legal regulations requested on 'straightforward statements about "blacks" that should be moved out'. He discerns an 'increasing intolerance towards allochtoneous residents' and in his view

The moment $<18$-year male $>$ became the victim of a robbery by allochtoneous youths, it seemed the autochtoneous residents saw their chance to start an offensive via the media in which the allochtoneous resident, Somali, Antillean or Moroccan in or around $<$ the square $>$ was pointed at for the feelings of personal insecurity of the residents on and around the square.

The head of police does not want to trivialise the feelings of insecurity that exist, but argues against 'combating nuisance on the basis of irritation, dominance, or intolerance'. ${ }^{25}$

The municipal authorities on the other hand offered no reservations with regard to the process as a whole, and CCTV is installed and a ban on gathering is imposed

25. The letter dates from early September 2003. The mayor addressed in this letter stepped down from his post due to health issues two weeks later and died soon thereafter. I have not been able to trace a response. The letter is translated by the author, the formulas between $<>$ replace name-specific references. within a year. Additionally, the municipal ordinance previously concerned only with the public consumption of alcoholic beverages was extended to also regulate other 'psychoactive substances', without any traceable political debate. The provision in the local bylaw on substance use was subsequently employed, and eventually in 2007, a ban on the public consumption of and trade in qat in was announced for the entire district. The motive formulated by the municipality was the nuisance experienced on the shopping square. In the official announcement of the ban, the municipality explicitly recognises it as a serious and far-reaching method, and motivates the intervention with the expectation that it will improve the situation on the shopping square. ${ }^{26}$

\subsubsection{Reiterating the Ban on Qat}

By the time I entered the shopping square to conduct fieldwork, the restrictive regulations had already been in place for several years, and specifically the ban on psycho-active substances - in practice a ban on using qat had waned from the collective consciousness on the square. As one resident recounts:

It would always be busy here with people who weren't shopping for their groceries if you know what I mean. [...] If I approached the police on the matter, those guys driving around in their patrol cars, they would give me a glazed look. They wouldn't know about the ban; those things peter out.

This resident undertakes to bring the ban back to the forefront. He eventually manages to get invited to make a presentation during a Town Council Meeting. He recounts how he went about making his point:

Look, my neighbour says 'no blacks for me'. That's also an opinion, people here are used to giving their opinion without any varnish. But it doesn't help what I was trying to do. (..) You get five minutes of allotted speaking time and not a second more. So, what can you tell in five minutes? What I did is I made a PowerPoint, referred to the ban in the local bylaw and showed them pictures I had made of what was happening in the neighbourhood.

As a result, the enforcement of the ban is picked up.

After the presentation, we got a whole squad of enforcers, what do you call those people with a blue jacket but without the service gun? It still goes on in the area, but nowhere near as bad as it was.

The municipality also circulates flyers with on the one side a reminder about the ban of qat and on the other a reminder about bans on making loud noise, littering and

26. For a further analysis on the policy process of specifically the ban on psycho-active substances, see D.A.M. Chevalier,'Truth or Tale? The Production, Selection and Interpretation of 'Evidence' Informing Municipal Policy on Public Use of Soft Drugs', in A. O'Gorman, G. Potter and J. Fountain (eds.), Evidence in Social Drug Research and Drug Policy. Lengerich: Pabst Science Publishers (2017) 85. 
defecating in the public space. A clear link was made in this formal broadcast between the use of qat and defecating in public space, and the connotation upset multiple recipients of the municipal flyer.

\subsection{Concluding}

The case under scrutiny here concerns restrictive regulations on a small neighbourhood shopping square in a provincial town in the Netherlands. The shopping square is a shared space of everyday life, that figures as the central space in a socio-economic and ethnic diverse neighbourhood. The square is used intensively by a wide variety of publics, and the way each of these publics use the space does not in all instances harmonise with the expectations and desires of other publics. The venue of the shopping square figures prominently in the daily lives of many different users. These users have diverging perspectives, needs, and interests with regard to the shared space of the shopping square. Those causing the proclaimed nuisance are themselves direct contenders for the space. The ban specifically on the public use of psychoactive substances is part of a package of municipal ordinances in place to regulate the behaviour on the square. The regulations have been instigated through public pressure and is a reaction to actual occurrences, the behaviour it targets is part of the social practices of specific publics for whom the shared space of the square figures prominently in their daily routines.

\section{Understanding Law}

At the surface a clear-cut measure to combat nuisance in the public realm, at closer inspection the ban turns out to be a lot less clear-cut. A qualitative analysis shows these bans to be the product of a power play over shared public space. In the following, first the analysis is traced of why the restrictive bans came about as they did. Second, it is traced how the regulations are perceived by the different participants to the public space after it has been effectuated.

\subsection{Formalisation into Law}

In the section on methodology, spatial thinker Henri Lefebvre was already introduced. To reiterate, Lefebvre refined the traditional dichotomy in spatial thinking - of planned versus lived space - into a conceptual triad consisting of the planned, perceived and lived dimensions continuously interacting and producing space. The planned dimension is the designed space, constructed by professionals and technocrats, emanating 'bureaucratic and political authoritarianism', and it is imposed on those who reside in space. The perceived dimension is the mental realm, where space is read and 'decoded' and imagined to be. The perceived dimension both 'propounds and presupposes' space, and mediates between the planned and the lived dimension. The lived dimension is space as it is actually encountered and directly lived through everyday experiences. It is 'the space of the inhabitants and users', 'the dominated (.) space, which the imagination seeks to change and appropriate'. ${ }^{27}$

Lefebvre furthermore posits that the three different realms of perceived, planned and lived must line up for an individual, in order for that individual to move from one realm to the other without confusion. ${ }^{28}$ In other words, when the lived dimension of space does not connect with the planned dimension, or when the perceived dimension of space does not concur with the lived dimension, confusion and disorientation ensue. People do not feel comfortable in a space in which the three dimensions do not line up for them, and will subsequently attempt to organise the space thus that the three dimensions get in synch with each other.

And this is precisely what we see happening in the shopping square. To a particular public on the square the lived experience on the square does not correspond with how they perceive the square should be. It used to be a very nice place where people would stroll on a Sunday to the ice-cream parlour, but now all the nice people have left. 'Sometimes it will be black with people here, literally!'. This mismatch between dimensions leads to a degree of unease, and subsequently an attempt is made to get the three dimensions in accordance with each other. By way of changing the planned dimension a change is sought in the lived experience of the square. Regulations are called for to ban certain behaviour from the square, curbing the typical use other participants to the shared space would like to make of that space. To recall, this is precisely what the head of police advocates against in his letter.

As we have seen though, the warning of the chief of police was to no avail: the regulations are legislated and implemented, including a specific ban on qat. And this in turn impacts the space for those targeted by the ban. How the Somali qat users perceive the square, as a public space set for socialising - and for them this includes the use of qat - is no longer congruent with the regulatory regime of the planned dimension of the space. The codification of social norms into legal bans is consequently a strategy employed in the contestation over space and the reality it constitutes. A ban on certain behaviour is an intervention in the planned dimension of space, aimed at bringing the lived dimension into line with the perceived dimension. The coming about of the restrictive regulations reflects the power contestations in that space.

\subsection{Law in Action}

Though the regulation banning the use of psychoactive substances represents the power play of one faction using a shared space, it doesn't by definition bring what its initiators had aspired. In the following the focus is put how the regulation is perceived and lived by the different publics on the square. Previously the publics on the square have been described on the basis of their use

Or in spatial terminology: respectively the potential and the effective environment. Cfm. H. Gans, People, Plans and Policies. Essays on Poverty, Racism and other National Urban Problems (1991), at 26.

28. Lefebvre, above n. 21, at 40 . 
of the square, in this section the definition of the different publics is tilted and the distinction made is that between entrepreneurs of the ban and targets of the ban. Moreover, a third group is discussed, that of the enforcers, as mediators between the entrepreneurs and the targets, while at the same time in their own relationship with the ban.

\subsubsection{The Entrepreneurs of the Ban}

Though the entrepreneurs of the ban have successfully seen their norms codified into formal regulations, the ban doesn't bring them the changes they had hoped for.

It's Tuesday morning and I have entered the Dutch bakery on Verdiplein. An employee is in the front helping customers, but the proprietress appears quickly from the back when she hears my voice. She's upset. On Saturday morning there had been a whole gang of youths, congregating at the entrance of the bakery. The entire façade of the bakery is glass, from ceiling to floor, bathing the shop in light and providing a wide overview of the square. And a front-row view of what occurs on the square and even more so in front of the bakery. The youths had been jostling and making loud noises and impolite gestures at them. It had been very aggravating to them and, even worse, intimidating for their customers. They had called the police, more than once. They did not have a direct number and had to go through the national operating system and explain their story every time. Eventually a patrol car showed up on the square early afternoon. It circled the square and came to a halt level to the youths. The police did not come out of their car. The proprietress repeats this several times, with exasperated unbelief. Instead they rolled down their window, called over to the youths and spoke a while, still seated in their car, with the youth who had ambled over to the patrol car. Quickly enough, they finished their conversation, appeared to exchange amicable goodbyes, and drove off again. The youths of course continued for a while in front of their shop, until they apparently got bored with it and moved on. She had been so unbelievably hopping mad. The youths should have been fined for congregating in a group, their behaviour was really off limits. And the police, she had no words for it, not even getting out of the car. She was so completely fed up with it all. That same afternoon they pulled down the municipal poster that had been in their shop front.

The proprietress is seriously disillusioned: the rules are clear and in effect, but they are not complied with and they are not enforced. The entire effort of the restrictive bans was to alter the lived sense of the shopping square. This has not been achieved. Additionally, the aggrieved behaviour has changed in meaning: it is no longer 'mere' misbehaving; it has become an intentional transgression of norms set by the institutional authorities on the square.

\subsubsection{Those Targeted by the Ban}

The Somalis have little doubt as to why the regulations have been installed:

The people from the high flat, they are coming to do their shopping, walking like this (he mimics pushing a walker), and they see the Somalis, all are black, all are noisy and the people they are scared. One day the police come and say we cannot be here anymore. ${ }^{29}$

The adolescents on the shopping square likewise understand the bans as being directed against their presence.

About those bans, this is our place, we are not leaving. We are fighting back, even if they barricade the square. [...] Why is this bench here? To sit on! Exactly, yeah. [...] This is our place, the spot where we come every day.

They understand that the presence of the bans reflect that the square is perceived to be unsafe by some of the other users. The adolescents blame this mistaken perception on popular media, steadfastly depicting immigrant youths as petty criminals.

Those old people, they sit in their homes and look at 'Opsporing Verzocht', ${ }^{30}$ and then they come here and they don't see the difference. They think we are all criminals.

The group that explained the impact of media depictions on how they were regarded in public space went into how hurtful this unjustified ascription was:

We are not like that. We are not like the gypsies who also come here in their big cars. They are really trash. They would rob an old lady for a few euros. We would never do that. If we rob someone, we take a mature guy, you know, one that can fight back.

The discourse in which the regulations came about resounds in the assessment of these regulations after their implementation. The regulations are felt to respond to an incorrect and unjust ascription of those who use the public space of the shopping square as a venue for their social existence. They are not perceived to be about maintaining the public order, but rather about attaining $a$ public order in which their presence does not figure.

\subsubsection{The Enforcers}

From a different point of view, one police officer responsible for the shopping square explains his position:

29. The quote comes from a conversation held in English and is not a translation.

30. Opsporing Verzocht roughly translates into 'wanted by the police'. It is a television program that has aired on Dutch TV since 1975. It is a joint venture between the Public Prosecutor, the police and the public broadcasting channel. Its format consists of the general public being asked to assist in solving police cases. 
We use the bans to keep the situation a bit under control. The shopping square is not a good place to control, if you enter the square everyone immediately disappears. You have to avoid getting caught up in a cat and mouse game, you really don't want that kind of situation. I prefer having them on the square and not branching out into the neighbourhood, into the residential areas. There they will really cause nuisance, much more than on the square.

The policemen do not explicitly concur that gathering and using psychoactive substances constitutes nuisance. For the institutional enforcers, the ban represents what it formally is: an instrument to uphold the public order in a literal sense. Whether the ban is enforced is dependent on the situation it is called upon, and the way an enforcer assesses that particular situation. One police officer contemplates:

Sometimes I get the impression everybody is practicing window dressing. A bylaw like that is installed to show, look, this is what we are doing. And the police are left holding the baby.

For the enforcers as well the context in which the bans came about does resonate in their appreciation of it. They recognise the symbolic signification of the ban, and they explicitly state that they do not enforce it for the mere sake of it. They view their assignment as keeping the square under control, in the service of all who use the square.

\subsubsection{Concluding}

The expectancy could be that the public that has managed to get their norm of appropriate behaviour on the square codified, is the dominant party in that space. The on-ground reality of the shopping square, however, shows a more nuanced situation. The regulation becomes something for the other parties to contend with, but they would seem to do this only at the practical level. For example, the Somalis on the shopping square adhere to the legal regulations forbidding the trade in qat and the gathering of more than three people, but only insofar as they foresee a possibility of the rule being enforced. The tactic of the Somalis is to change their lived dimension of the square: they quickly break up congregations when police are spotted to approach the square, the trade in qat is moved to dealings in the enclosed realm of a parked car, and when qat is still chewed on the square it happens in a covert manner. They do not, however, remove from the space, the legal regulations are not sufficient to establish or maintain dominance in the space for those who entrepreneured them.

\subsection{The Storyline of Law}

This one local regulation vividly demonstrates that law has a life both before and after its legislative delivery. The manner in which the regulation has come about continues on in how the regulation is perceived once it is formalised. The moral entrepreneurs feel that their achieved regulation should be complied with and if need be enforced, regardless. Those targeted by the ban understand the regulation to be of hostile intent, and adjust insofar as necessary to avoid prosecution. The police regard the ban as an instrument in their work to secure public order, thus as a means to an end, rather than a goal in itself. These perceptions in turn loop back to how also the authority that has emanated the formal law is perceived.

\section{Conclusion and Discussion}

Law is a continuous process of becoming. It has a storyline that commences before its actual legislative codification and that continues beyond this moment of institutional formalisation. The case study presented in this article demonstrates how qualitative research figures in exploring the storylines leading to and leading from the legal inception in the books, offering a comprehensive view of the process in which law continuously becomes. The micro event of a local bylaw on a neighbourhood shopping square of a provincial town shows the power plays connected to law. A seemingly straightforward response to undesirable situations of nuisance, the ban under scrutiny here harbours dynamics that concern the inclusion and exclusion of those falling outside the acceptance of the dominant group. In the case study presented here, the motions of exclusion were directed at ethnic others. In two parallel cases researched under the same umbrella, dynamics of exclusion occurred along fault lines of socio-economic differences and ideological-religious orientations. Though the characteristics on which 'the other' was defined differed, the mechanism through which law was morally entrepreneured bottom-up to determine the accommodating quality of a shared space was equal. Likewise, the perceptions and experiences of publics propounding the ban and the publics targeted by the ban ran parallel. The qualitative investigation demonstrates that the storyline of law, before its formal emergence, is pivotal to understanding why it comes about, and how this figures in the way formal law subsequently operates in everyday reality.

Formalised law is never the truth, but one of many truths. Whose truth makes the books, how this happens and under which conditions in turn impacts how law in books is subsequently perceived and experienced in the context that brought it about. This mechanism increases in relevance as diversity in society increases. The term 'superdiversity' has been conceived to express the rapid augmentation of societal diversity in terms of culture, ethnicity and religion. ${ }^{31}$ One of the consequences of an increasingly diversifying society is that common ground is lost on which people communicate and negotiate everyday conviviality. In this setting of superdiversity it

31. S. Vertovec, 'Super-diversity and Its Implications', 30(6) Ethnic and Racial Studies 1024 (2007); F. Meissner and S. Vertovec, 'Comparing Super-diversity', 38(4) Ethnic and Racial Studies 541 (2015); M. Crul, J. Schneider and F. Lelie, Superdiversiteit (2013). 
has been proposed that law could well be the most viable bridge across differences and function as facilitating framework. Law could fulfil the function of a minimal, formal and procedural moral in situations in which traditional forms of social bonding lose their effectiveness. ${ }^{32}$ In contemplating such propositions there is a danger of unconsciously understanding law to have a measure of neutrality. When such high expectations are placed on the bridging potential of law, it is pivotal to fully understand law and its storylines; the context from which it arises, the power dynamics it incorporates and how - to circle back to Pound - the rules that 'purport to govern the relations of man and man' and the rules 'that in fact govern them' are perceived by 'present-day life'. ${ }^{33}$

32. See e.g.: J. Habermas, Between Facts and Norms. Contributions to a Discourse Theory on Law and Democracy (1996 [1992]) and C.J.M. Schuyt, 'Bronnen van Juridisering en hun Confluentie', 2 Nederlands Juristenblad. Special: Juridisering 925 (1997). I discuss this point more elaborately in 'The production of law': Law in action in the everyday and the juridical consequences of juridification, (38) 1 Recht der Werkelijkheid, 116 (2017).

33. Pound, above n. 1, at 22. 